\title{
Experimental model for optimizing dental implant therapy in the posterior maxilla
}

\author{
VICTOR NIMIGEAN ${ }^{1}$, DAN IONUŢ SĂLĂVĂSTRU ${ }^{2}$, VANDA ROXANA NIMIGEAN*, \\ ALEXANDRU POLL ${ }^{1}$, VALENTIN DANIEL SÎRBU ${ }^{4}$, SIMONA ANDREEA MORARU ${ }^{3}$, \\ DENISE PAULINE ORENSTEIN ${ }^{5}$, MARIA JUSTINA ROXANA VÎRLAN ${ }^{3}$
}

\author{
${ }^{1}$ Anatomy Department, Faculty of Dental Medicine, Carol Davila University of Medicine and \\ Pharmacy, Bucharest, Romania \\ ${ }^{2}$ Private dental practice, Bucharest, Romania \\ ${ }^{3}$ Oral Rehabilitation Department, Faculty of Dental Medicine, Carol Davila University of Medicine \\ and Pharmacy, Bucharest, Romania \\ ${ }^{4}$ Implant-Prosthetic Therapy Department, Faculty of Dental Medicine, Carol Davila University of \\ Medicine and Pharmacy, Bucharest, Romania \\ ${ }^{5}$ Private dental practice, Frankfurt on the Main, Germany
}

\begin{abstract}
This research aimed to develop an experimental animal model for the evaluation of the posterior maxillary alveolar bone and further selection of the design for a dental implant with high osseointegration potential.

Ten dried skulls of common adult dogs, Canis familiaris, were used in this study. In order to achieve the experimental model, two working methods were performed: imaging morphometry and direct morphometry. The measurements were accomplished for the purposes of determining the dimensions of the buccal and palatal alveolar cortical bone in the target location, the maxillary premolar region. The width and height of available bone were also recorded. Data analysis was performed using Student's t-test $(\mathrm{P} \leq 0.05)$ and the Stata MP/13 software.

Comparable results were obtained by both imaging and direct morphometry methods. The experimental implant was customized from the dimensional point of view and considering the most appropriate implant design.
\end{abstract}

Keywords Experimental model, available bone, morphometry, dental implant, osseointegration.

To cite this article: NIMIGEAN V, SĂLĂVĂSTRU DI, NIMIGEAN VR, POLL A, SîRBU VD, MORARU SA, ORENSTEIN DP, VÎRLAN MJR. Experimental model for optimizing dental implant therapy in the posterior maxilla. Rom Biotechnol Lett. 2020; 25(1): 1170-1177. DOI: $10.25083 / \mathrm{rbl} / 25.1 / 1170.1177$

*Corresponding author: VANDA ROXANA NIMIGEAN, Associate Professor, Head of Oral Rehabilitation Department, Faculty of Dental Medicine, Carol Davila University of Medicine and Pharmacy, 17-23 Calea Plevnei Street, 060015 Bucharest, Romania, Phone: +40721561848 E-mail: vandanimigean@ yahoo.com 


\section{Introduction}

Using animals with experimental purpose is quite an old scientific practice, which is still developing, due to its benefits to medical research [1].

European and Romanian legislations in force advocate for a reduction in the number of experimental studies on animals and recommend the use of alternative methods [2, 3]. However, when these studies are carried out, different procedures should be performed under anesthesia in order to reduce stress and to eliminate any type of pain $[2,3]$.

The number of animals used in scientific experiments remains high even in the third millennium. In Germany, for example, in 2001, approximately 2,126,000 animals were used in experiments (D.I. SĂLĂ VĂSTRU [4]).

Experiments on animals obtain results with a high degree of relevance to humans, due to the phylogenetic comparisons and morphophysiological similarities between animals and humans (A. POLL \& al [5], X. STRUILLOU \& al [6], J.C. SALEN [7], A. POLL \& al [8]).

In this case, some particular morphological patterns at the maxillary bone level may suggest certain predisposition to post-treatment complications (A.M. ENACHE \& al [9]).

Most higher education institutions have created ethics committees that endorse animal research or not. Unfortunately, only a small part of the members of these committees have research skills, and for this reason the researcher reaches the point of 'reporting' with much detail all experimental procedures. These reporting procedures may lead to delays or even cause the study to stop (D.I. SĂLĂVĂSTRU [4]).

Implant-supported oral rehabilitation is a current therapeutic option in dental medicine. The union between implant and bone is called osseointegration, and it was first introduced as a concept by Per-Ingvar Branemark in 1969 (R.S. JAYESH and V. DHINAKARSAMY [10]). He defined osseointegration as 'A direct connection between living bone and a load-carrying endosseous implant at the light microscopic level' (R.S. JAYESH and V. DHINAKARSAMY [10]). Nowadays osseointegration is considered 'a new field of clinical usage of biotechnology' (R.S. JAYESH and V. DHINAKARSAMY [10]).

Different factors are responsible for the success of dental implant treatment, including the topography of the edentulous space and the type of subsequent restoration (D.I. SĂLĂVĂSTRU [4]). Hence dental implant location is one of the aspects that could influence the outcome of such treatment (L. TOLSTUNOV [11]). Due to the insufficient bone quality and quantity, the posterior maxilla is considered to be one of the most challenging anatomic locations for the dental implant placement (D. DOLANMAZ $\&$ al [12]).

The aim of this study was to quantitatively and qualitatively evaluate the posterior maxillary alveolar bone in order to develop the design of a dental implant with high potential for osseointegration and ultimately increase the long-term performance of dental implant treatment in this anatomic region.

An experimental animal model was used in this respect, namely the domestic dog, Canis familiaris, because of the dimensional and embryological similarities between the canine and human maxillae and mandibles, as illustrated by a careful literature review (X. STRUILLOU \& al [6], C. TUTT [13]).

\section{Materials and Methods}

The skulls of ten medium-sized dogs, common breed, Canis familiaris, which died from natural causes, were used for the study. The research was organized and carried out in accordance with the legislation in force.

The maxillary premolar region was selected as the target location for the appropriate experimental model, due to the anatomical configuration of the maxilla and because of the direct access for future surgical procedures. Measurements on bucco-palatal sections were performed for the purpose of determining the size of the buccal and palatal alveolar bone plates, as well as the dimensions and quality of the available bone. The tooth topography in the alveolar processes and the neighborhood of the maxillary sinus floor and the nasal floor were also analyzed.

In order to define the experimental model, two working methods were established: imaging morphometry and direct morphometry on canine dried skulls.

\section{Direct morphometry on canine dried skulls}

The measurements were carried out on the ten canine dried skulls. Five bucco-palatal sections were bilaterally performed in the maxillary premolar region, resulting in a total of 100 sections. The sectioning was performed with $\varnothing 30 \mathrm{~mm}$ and $\varnothing 40 \mathrm{~mm}$ mandrel mounted cutting edge diamond discs, using a dental micromotor at conventional speed. The sectioning instruments were provided by a dental office.

The maxillary sections were measured with a digital Workzone calliper (Globaltronics GmbH, Singapore) in order to determine the thickness of the alveolar external bone plates and the width of the alveolar processes.

\section{Imaging morphometry on canine dried skulls}

The measurements regarding the thickness of the alveolar external bone plates and the width and height of the alveolar processes were completed through computed tomography (CT) scans on the maxillary premolar regions. The CT scans were performed using the 6-slice configuration computed tomography scanner (Siemens Somatom 6 CT scanner), with the following technical parameters: 0.85 pitch, $1.25 \mathrm{~mm}$ thickness of sections, $6 \times 1 \mathrm{~mm}$ section collimation, $120 \mathrm{kV}$ and $45 \mathrm{~mA}$. The bucco-palatal sections were bilaterally performed through the maxillary alveolar process at the level of the first three premolars, resulting in a total of 60 bucco-palatal maxillary sections, 30 on the right sides and 30 on the left sides. The width of the sections represents the real thickness of the reconstructed images. 


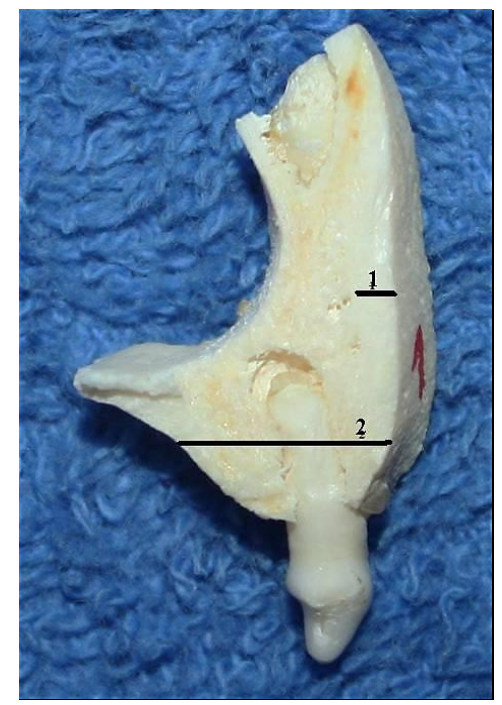

Figure 1. Bucco-palatal section at the level of the left maxillary second premolar:

1 - the thickness of the alveolar buccal bone plate;

2 - the bucco-palatal width of the alveolar process.

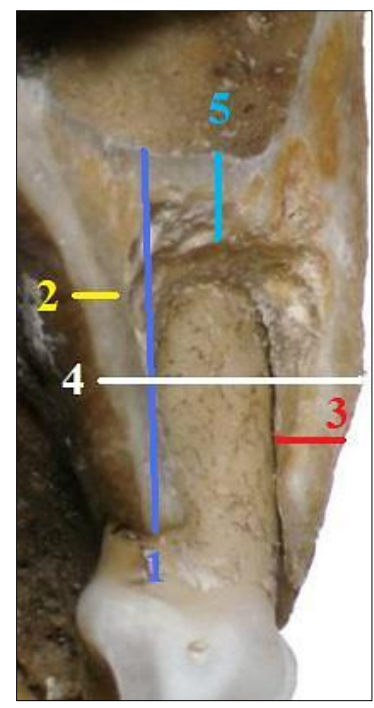

Figure 2. Bucco-palatal section at the level of the left maxillary second premolar:

1 - the height of the available bone;

2 - the thickness of the alveolar palatal bone plate;

3 - the thickness of the alveolar buccal bone plate;

4 - the width of the available bone;

5 - the thickness of the maxillary sinus floor.

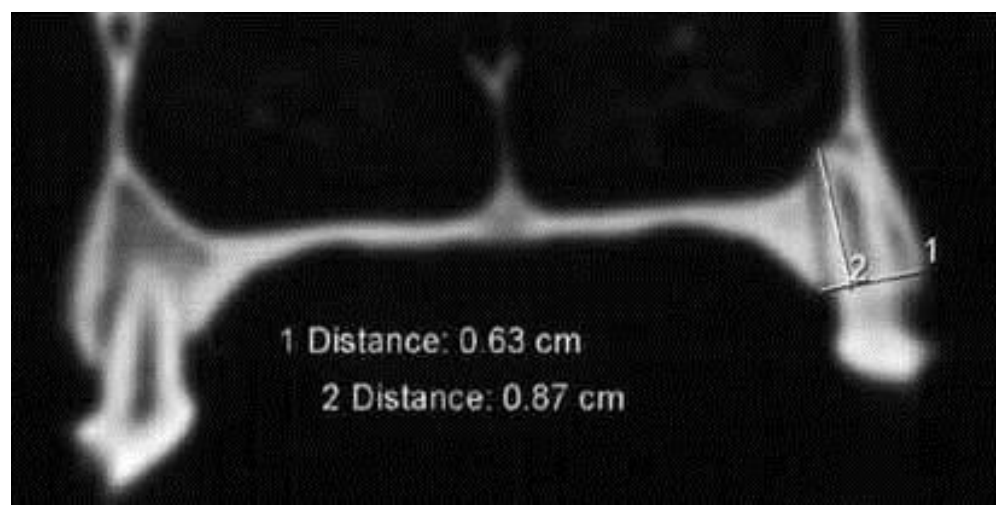

Figure 3. CT image: coronal section through alveolar processes in the maxillary premolar region:

1 - the width of the maxillary alveolar process;

2 - the height of the maxillary alveolar process.

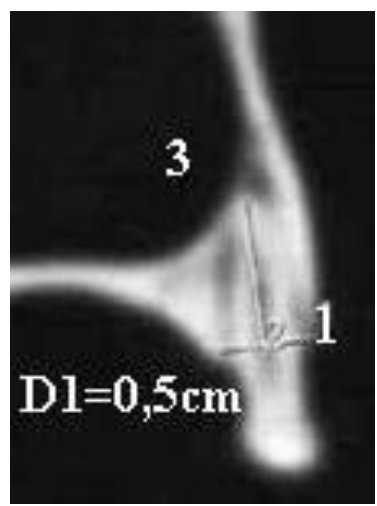

Figure 4. CT image: bucco-palatal section at the level of the maxillary left second premolar: 1 - the width of the maxillary alveolar process; 2 - the height of the maxillary alveolar process; 3 - the nasal fossa.

\section{Results}

The data obtained were statistically processed. The arithmetic mean, standard deviation (SD), standard error (SE), median, minimum and maximum values were calculated. Data were compared with the Student's t-test. The test was used bilaterally, and the statistical significance threshold was set at $\mathrm{p} \leq 0.05$. The results were analyzed using the Stata MP/13 software.

After the morphometric and radiographic analysis of the quality of the available bone, and taking into account medical literature data, it was determined that the available bone was D2-D3 categories of density (D.I. SĂLĂVĂSTRU
[4]). In $50 \%$ of the cases the density of the available bone in the right maxillary premolar region was D2 and in 50\% of the cases it was D3. In $46 \%$ of the cases the density of the available bone in the left maxillary premolar region was D2, while in $54 \%$ of the cases it was D3, as shown in figures 5-6.

The results obtained by direct morphometry performed on maxillary bucco-palatal sections were analyzed and statistically processed using the Student's t-test, as presented in Tables 1-4.

Table 1 shows the results on the size (thickness) of the alveolar buccal bone plate $(\mathrm{mm})$ determined by direct morphometry performed on the maxillary premolar region 
both on the right and the left sides. The values vary between 0.3-1.4 mm. The mean of the alveolar buccal bone plate thickness was higher in the D2 bone on both the right and the left maxillary sides. The mean of the alveolar buccal

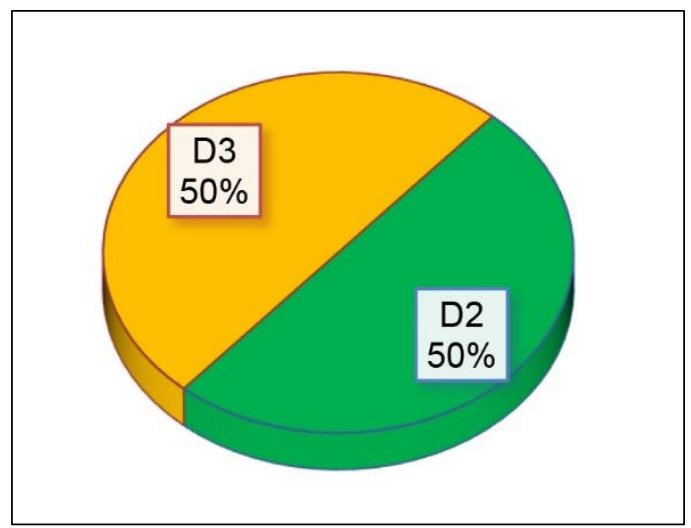

Figure 5. The density of the available bone in the right maxillary premolar region. bone plate thickness on the right side was $0.82 \mathrm{~mm}$, compared to $0.81 \mathrm{~mm}$ on the left side. The SD value was 0.24 . This alveolar bone plate is rather thin.

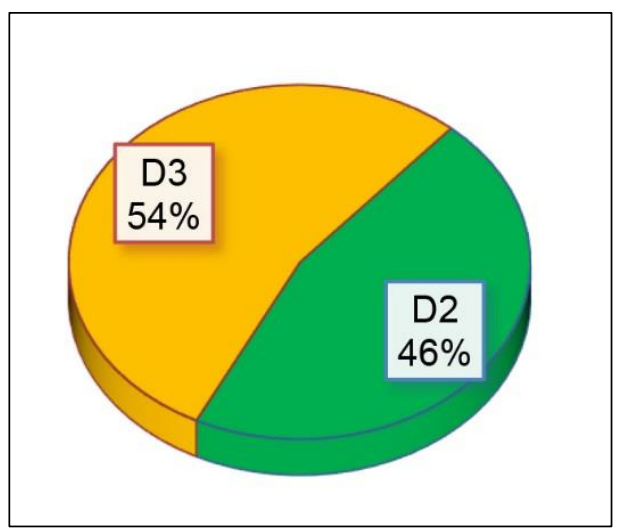

Figure 6. The density of the available bone in the left maxillary premolar region.

Table 1. The thickness of the alveolar buccal bone plate

(determined by direct morphometry on maxillary bones of canine dried skulls)

\begin{tabular}{|c|c|c|c|c|c|c|c|c|}
\hline \multicolumn{9}{|c|}{ The alveolar buccal bone plate (mm) } \\
\hline Side & $\begin{array}{c}\text { Bone } \\
\text { density }\end{array}$ & $\mathrm{N}$ & $\%$ & Mean & SD & Minimum & Median & Maximum \\
\hline \multirow[t]{4}{*}{ Right } & D2 & 25 & 50 & 0.85 & 0.21 & 0.5 & 0.8 & 1.22 \\
\hline & D3 & 25 & 50 & 0.79 & 0.26 & 0.3 & 0.7 & 1.4 \\
\hline & Total & 50 & 100 & 0.82 & 0.24 & 0.3 & 0.8 & 1.4 \\
\hline & \multicolumn{8}{|c|}{ Student's t-test D2 vs. D3; $p=0.393$} \\
\hline \multirow[t]{4}{*}{ Left } & D2 & 23 & 46 & 0.83 & 0.21 & 0.5 & 0.8 & 1.3 \\
\hline & D3 & 27 & 54 & 0.80 & 0.27 & 0.4 & 0.74 & 1.2 \\
\hline & Total & 50 & 100 & 0.81 & 0.24 & 0.4 & 0.8 & 1.3 \\
\hline & \multicolumn{8}{|c|}{ Student's t-test D2 vs. D3; $p=0.641$} \\
\hline \multicolumn{9}{|c|}{ Student's t-test right part vs. left part; $p=0.884$} \\
\hline
\end{tabular}

N: Number of sections; SD: standard deviation; Student's t-test: analysis of variance.

Table 2. The thickness of the alveolar palatal bone plate

(determined by direct morphometry on maxillary bones of canine dried skulls)

\begin{tabular}{|c|c|c|c|c|c|c|c|c|}
\hline \multicolumn{9}{|c|}{ The alveolar palatal bone plate $(\mathrm{mm})$} \\
\hline Side & $\begin{array}{c}\text { Bone } \\
\text { density }\end{array}$ & $\mathrm{N}$ & $\%$ & Mean & SD & Minimum & Median & Maximum \\
\hline \multirow{4}{*}{ Right } & D2 & 25 & 50 & 1.42 & 2.22 & 0.6 & 1.0 & 1.2 \\
\hline & D3 & 25 & 50 & 1.05 & 0.32 & 0.58 & 1.03 & 1.6 \\
\hline & Total & 50 & 100 & 1.23 & 1.58 & 0.58 & 1.0 & 1.2 \\
\hline & \multicolumn{8}{|c|}{ Student's t-test D2 vs. D3; $p=0.418$} \\
\hline \multirow[t]{4}{*}{ Left } & D2 & 23 & 46 & 1.50 & 2.52 & 0.6 & 1.0 & 1.3 \\
\hline & D3 & 27 & 54 & 1.02 & 0.29 & 0.56 & 1.0 & 1.62 \\
\hline & Total & 50 & 100 & 1.24 & 1.72 & 0.56 & 1.0 & 1.3 \\
\hline & \multicolumn{8}{|c|}{ Student's t-test D2 vs. D3; $p=0.329$} \\
\hline & & & & st right & left $p$ & $=0.979$ & & \\
\hline
\end{tabular}

N: Number of sections; SD: standard deviation; Student's t-test: analysis of variance. 
Table 2 presents the results on the size (thickness) of the alveolar palatal bone plate $(\mathrm{mm})$ determined by direct morphometry performed on the maxillary premolar region on both the right and the left sides. The measured values vary between $0.56-1.62 \mathrm{~mm}$. The mean of the alveolar palatal bone plate thickness was also higher on the D2 bone, both on the right and the left maxillary sides. The mean of the alveolar palatal bone plate thickness was $1.23 \mathrm{~mm}$ on the right side, while on the left side it was $1.24 \mathrm{~mm}$. The SD value was 1.65 . The alveolar palatal bone plate is thicker than the alveolar buccal bone plate.

Table 3. The width of the available bone (determined by direct morphometry on maxillary bones of canine dried skulls)

\begin{tabular}{|c|c|c|c|c|c|c|c|c|}
\hline \multicolumn{8}{|c|}{ The width of the available bone (mm) } \\
\hline Side & $\begin{array}{c}\text { Bone } \\
\text { density }\end{array}$ & $\mathrm{N}$ & $\%$ & Mean & SD & Minimum & Median & Maximum \\
\hline Right & D2 & 25 & 50 & 5.79 & 1.04 & 4.2 & 5.7 & 8 \\
\hline & D3 & 25 & 50 & 5.95 & 1.22 & 3.2 & 5.7 & 8.2 \\
\hline & Total & 50 & 100 & 5.87 & 1.2 & 3.2 & 5.7 & 8.2 \\
\hline & D2 & 23 & 46 & 5.67 & 0.99 & 4 & 5.5 & 7.6 \\
\hline Left & D3 & 27 & 54 & 6.00 & 1.20 & 3.3 & 5.8 & 8.3 \\
\hline & Total & 50 & 100 & 5.85 & 1.11 & 3.3 & 5.65 & 8.3 \\
\hline & \multicolumn{7}{|c|}{ Student's t-test D2 vs. D3; $\mathrm{p}=0.295$} \\
\hline
\end{tabular}

$\mathrm{N}$ : Number of sections; SD: standard deviation; Student's t-test: analysis of variance.

Table 3 shows the width of the available bone determined by direct morphometry performed on the maxillary premolar region, both on the right and the left sides. The width varies between $3.2-8.3 \mathrm{~mm}$. The mean of the available bone width is lower in the D2 bone compared to the D3 bone, both on the right and the left maxillary sides. The mean of the available bone width on the right maxillary premolar region was $5.87 \mathrm{~mm}$, while on the left side it was $5.85 \mathrm{~mm}$. So the values of the bone width on the right and on the left sides were relatively close, at a SD of 1.15. These values show that in terms of width, the available bone has the appropriate size to accept an endosseous implant, dimensionally close to the implant used in the human species.

Table 4. The height of the available bone

(determined by direct morphometry on maxillary bones of canine dried skulls)

\begin{tabular}{|c|c|c|c|c|c|c|c|c|}
\hline \multicolumn{8}{|c|}{ The height of the available bone (mm) } \\
\hline Side & $\begin{array}{c}\text { Bone } \\
\text { density }\end{array}$ & $\mathrm{N}$ & $\%$ & Mean & SD & Minimum & Median & Maximum \\
\hline Right & D2 & 25 & 50 & 8.94 & 0.90 & 7.2 & 9 & 11 \\
\hline & D3 & 25 & 50 & 8.99 & 1.35 & 7 & 8.6 & 12.1 \\
\hline & Total & 50 & 100 & 8.96 & 1.14 & 7 & 9 & 12.1 \\
\hline & D2 & 23 & 46 & 8.95 & 1.03 & 7.3 & 9.1 & 11.5 \\
\hline Left & D3 & 27 & 54 & 9.09 & 1.32 & 7 & 9 & 13 \\
\hline & Total & 50 & 100 & 9.03 & 1.19 & 7 & 9.05 & 13 \\
\hline & \multicolumn{7}{|c|}{ Student's t-test D2 vs. D3; p = 0.625 } \\
\hline
\end{tabular}

N: Number of sections; SD: standard deviation; Student's t-test: analysis of variance.

Table 4 illustrates the height of the available bone determined by direct morphometry performed on the maxillary premolar region, both on the right and the left sides. As can be seen in Table 4, the height of the available bone varies between 7-13 $\mathrm{mm}$. The mean of the available bone height is also lower in the D2 bone, both on the right and the left maxillary sides, compared to the D3 bone. The mean of the available bone height on the right maxillary premolar region was $8.96 \mathrm{~mm}$, and on the left side it was
$9.03 \mathrm{~mm}$. So, the two bone areas were dimensionally close in terms of bone height. SD was 1.16. The results show that the available bone height in the maxillary premolar region is suitable to accept an endosseous implant, dimensionally close to the implant used in the human species.

Tables 5 and 6 show imaging measurements (CT measurements) regarding the characteristics of the available bone, analyzed and statistically processed with the help of the Student's t-test. 
Table 5. The height of the available bone (measurements on CT images of canine dried maxillary bones)

\begin{tabular}{|c|c|c|c|c|c|c|}
\hline \multicolumn{7}{|c|}{ The height of the available bone (mm) } \\
\hline Side & N & Mean & SD & Minimum & Median & Maximum \\
\hline Right & 10 & 8.32 & 0.62 & 7.2 & 8.3 & 9.5 \\
\hline Left & 10 & 8.25 & 0.69 & 7.6 & 8.05 & 10 \\
\hline \multicolumn{7}{|l|}{ Student's t-test right part vs. left part; $\mathrm{p}=0.815$} \\
\hline
\end{tabular}

$\mathrm{N}$ : Number of canine dried skulls; SD: standard deviation; Student's t-test: analysis of variance.

Table 5 presents the results regarding the height of the available bone on the right and left maxillary premolar regions, measured on CT images. Measurements vary between 7.2-10 $\mathrm{mm}$. The mean of the bone height on the right maxillary premolar region was $8.32 \mathrm{~mm}$, while on the left maxillary premolar region it was $8.25 \mathrm{~mm}$. Therefore, the two bone areas are dimensionally close in terms of bone height at a SD value of 0.65 .
The imaging results regarding the height of the available bone are comparable to those obtained through direct morphometry. So, this result emphasizes the previous observation regarding the volume of the available bone, which was found appropriate to accept an endosseous implant, dimensionally close to the implant used in the human species.

Table 6. The width of the available bone (determined on CT images of dried canine maxillary bones)

\begin{tabular}{|c|c|c|c|c|c|c|}
\hline \multicolumn{7}{|c|}{ The width of the available bone (mm) } \\
\hline Side & $\mathrm{N}$ & Mean & SD & Minimum & Median & Maximum \\
\hline Right & 10 & 5.93 & 0.83 & 4.8 & 5.85 & 7 \\
\hline Left & 10 & 5.85 & 1.25 & 3.8 & 5.75 & 7.9 \\
\hline \multicolumn{7}{|c|}{ Student's t-test right part vs. left part; $\mathrm{p}=0.867$} \\
\hline
\end{tabular}

$\mathrm{N}$ : Number of canine dried skulls; SD: standard deviation; Student's t-test: analysis of variance.

Table 6 shows the results concerning the width of the available bone on the right and left maxillary premolar regions, measured by imaging methods (CT). This size varies from $3.8 \mathrm{~mm}$ to $7.9 \mathrm{~mm}$.

The mean of the available bone width was found to be $5.93 \mathrm{~mm}$ on the right maxillary premolar area and $5.85 \mathrm{~mm}$ on the left maxillary premolar area. Thus, the two bone areas (left and right maxillary premolar areas) were considered to be dimensionally close in terms of bone width, at a SD value of 2.04 .

The imaging results regarding the bone width are also comparable to those obtained by direct morphometry, demonstrating that the available bone size in the canine species is suitable for an endosseous implant, dimensionally close to the implant used in the human species.

\section{Discussion}

The maxillary premolar region, a challenging anatomical region for dental implant placement, due to bone density and neighborhood anatomical structures, was selected as the target experiment location.

After gathering the results obtained both by imaging morphometry and by direct morphometry regarding the dimensional characteristics of the available bone, the features of the future experimental dental implant to be applied at the level of the target area have been established, namely a conical body shape, 8 millimeters length, $3 \mathrm{~mm}$ diameter of the cervical area and $2 \mathrm{~mm}$ diameter of the apical portion. This implant model was further customized in terms of dental implant material, implant body design and surface topography. For this purpose descriptions from a thorough specialized literature review were correlated with the morphometric data obtained in this study.

There is a competition between ceramics and titanium as dental implant materials (R.B. OSMAN and M.V. SWAIN [14]). It is well known that bioactive ceramics are integrated into bone metabolism and achieve a better physical-chemical connection with the bone (adhesion osteogenesis) (G.E. ROMANOS [15]). However, they provide future bone-implant contacts which are similar to bone-titanium implant contacts (G.E. ROMANOS [15]). These days, inert ceramics (oxide ceramics) are used for dental implants production, zirconium oxide (zirconia) being the most appreciated in this category (R.B. OSMAN and M.V. SWAIN [14]). Pure titanium and titanium alloys are commonly used as dental implant materials due to their excellent mechanical strength, chemical stability and biocompatibility (H. KIM \& al [16]). Titanium biocompatibility is closely related to surface roughness, chemical treatment and surface characteristics (H. KIM \& al [16]). Research also indicates similar osseointegration and biocompatibility for zirconium oxide and titanium implants (B. MÖLLER \& al [17]).

Pure titanium (unalloyed titanium) Grade II was decided to be used as dental implant material in our experimental studies.

A threaded implant body design was selected for our experimental model. As Misch has described, implant threads have three primary functions: the maximization of initial fixation and bone contact, the enhancement of the functional area and the stress dissipation at the 
bone-implant interface (C. MISCH [18], M.M. OSWAL $\&$ al [19]). Increased stability and stress-induced bone formation are also achieved by using threaded dental implants (M.M. OSWAL \& al [19]).

Although clinical evidence is unclear about the effects of the shape of dental implant threads on primary stability, the thread design may have an effect on primary stability in the case of low density bone. This effect was not described in the cases with high density bone (D.I. SĂLĂVĂSTRU [4]).

In accordance with the results of our study, we decided that the experimental implant should have a progressive increase of the thread depth (lesser depth in the coronal portion and greater depth in the apical portion), rounded edge threads and $1.25 \mathrm{~mm}$ pitch.

The influence of dental implant surface roughness on osseointegration has been demonstrated in vitro, as well as in vivo. Cell attachment, much better for rough surfaces, is correlated with a higher degree of synthesis of growth factors (K. KIESWETTER and Z. SCHWARTZ [20], D. BUSER \& al [21]). Increasing complexity of the dental implant surface morphology influences integration, particularly at the trabecular bone level (M. WONG \& al [22]). The implant surface topography and its impact on healing play an important role in terms of biological criteria that can guide the development of future tissue at the boneimplant interface. Different research groups have shown that the biological response can be influenced by the implant surface modifications (C.M. STANFORD [23]), D. ARYA \& al [24]). Altering our experimental implant surface topography was performed by sandblasting with $200 \mu \mathrm{m}$ aluminium oxide particles.

Many experimental animal studies have been developed over the last decade, in order to increase long-term performance of dental implants (C. OGUNSALU \& al [25], C. OGUNSALU \& al [26], K. KON \& al [27]).

On such experimental models, histopathological and immunohistochemical studies on autogenous bone grafts integration and bone, epithelium and connective tissue integration to dental implants can be further performed (V. NIMIGEAN \& al [28], V. NIMIGEAN \& al [29], V. NIMIGEAN \& al [30]). Other experimental models were aimed at investigating the histological and immunohistochemical changes of pulp tissue exposed to different biomaterials (M.J. TUCULINA \& al [31]).

Experimental animal models may, however, be limited by scientific constraints in their applicability to the human species. Besides, the increased regulatory restrictions also limit to some extent the experimental animal models (A. KNIGHT [32], M. LEIST \& al [33], W. LILIENBLUM \& al [34]).

\section{Conclusions}

The benefits of experimental animal studies must be viewed with caution and should not be considered indispensable in the field of clinical research. Also, these models should always be subordinated to well-defined scientific goals.

\section{Conflict of interests}

The authors declare that they have no conflict of interests.

\section{Acknowledgments}

Part of this research was conducted within Dan Ionuţ Sălăvăstru's $\mathrm{PhD}$ Thesis, "Clinical and experimental studies regarding the osseointegration of dental implants".

The stipulations in the European Council's Directive 86/609/EEC and Directive 2010/63/EU, for the protection of animals used for scientific purposes, were complied with. Also, the study was endorsed by the Ethics Committee of the Faculty of Veterinary Medicine in Bucharest and the study was in accordance with local laws and regulations.

\section{Author contribution}

Author Victor Nimigean, author Dan Ionuţ Sălăvăstru, author Alexandru Poll, author Valentin Daniel Sîrbu and author Simona Andreea Moraru have equal contributions to this paper and thus are main authors.

\section{References}

1. Seventh Report from the Commission to the Council and the European Parliament on the Statistics on the number of animals used for experimental and other scientific purposes in the member states of the European Union COM(2013)859/final. Available at: Http://ec.europa.eu/environment/chemicals/lab_anima 1s/reports_en. htm Retrieved on the 3rd of March 2014.

2. Directive 2010/63/EU of the European Parliament and of the Council of 22 September 2010 on the protection of animals used for scientific purposes. Available at: https://eur-lex.europa.eu/eli/dir/2010/63/oj Retrieved on the $1^{\text {st }}$ of December 2018.

3. Law no. 43/2014 on the protection of animals used for scientific purposes, published on The Official Monitor of Romania, Part I, the $6^{\text {th }}$ of May 2014, item 326.

4. D.I. SĂLĂVĂSTRU, Studii clinice şi experimentale privind integrarea osoasă a implanturilor dentare (Clinical and experimental studies regarding the osseointegration of dental implants). PhD Thesis. Carol Davila University of Medicine and Pharmacy, Bucharest, Romania (2014).

5. A. POLL, C.A. MINCULESCU, V.R. NIMIGEAN, D. BADITA, R.A. BALACEANU, D.L. PAUN, S.A. MORARU, V. NIMIGEAN, Experimental model for the study of autogenous mandibular bone grafts integration. Rom Biotechnol Lett, 23(3), 13681-13689 (2018).

6. X. STRUILlOU, H. BOUTIGNY, A. SOUEIDAN, P. LAYROLLE, Experimental animal models in periodontology: a review. Open Dent J, 29(4), 37-37 (2010).

7. J.C. SALEN, Animal models - Principles and problems. In: Svendsen P., Han J. (ed.) - Handbook of laboratory animal science. Vol. II - Animal models. CRC Press, 1-6 (1994).

8. A. POLL, V.R. NIMIGEAN, D. BADITA, R.A. BALACEANU, S.C. CISMAS, P. PERLEA, S.A. MORARU, V. NIMIGEAN, In vivo experimental 
model for the evaluation of dental implant integration. Rom Biotechnol Lett, 23(2), 13505-13510 (2018).

9. A.M. ENACHE, V.R. NIMIGEAN, F. MIHALTAN, A.C. DIDILESCU, I. MUNTEANU, V. NIMIGEAN, Assessment of sagittal and vertical skeletal patterns in Romanian patients with obstructive sleep apnea. Rom J Morphol Embryol, 51(3), 505-508 (2010).

10. R.S. JAYESH, V. DHINAKARSAMY, Osseointegration. J Pharm Bioallied Sci, 7(Suppl 1), S226-S229 (2015), doi:10.4103/0975-7406.155917.

11. L. TOLSTUNOV, Implant zones of the jaws: implant location and related success rate. J Oral Implantol, 33(4), 211-220 (2007).

12. D. DOLANMAZ, F.C. SENEL, Z.Ö. PEKTAS, Dental implants in posterior maxilla: diagnostic and treatment aspects. Int J Dent, 2012:132569 (2012).

13. C. TUTT, Small Animal Dentistry. Blackwell Publishing Ltd, Oxford, 19-31, 95-105, 229-32 (2006).

14. R.B. OSMAN, M.V. SWAIN, A Critical Review of Dental Implant Materials with an Emphasis on Titanium versus Zirconia. Materials (Basel), 8(3), 932-958 (2015).

15. G.E. ROMANOS, Immediate Loading of Endosseous Implants in the Posterior Area of the Mandible. Quintessenz Verlags, Frankfurt am Main (2003).

16. H. KIM, S.H. CHOI, J.J. RYU, S.Y. KOH, J.H. PARK, I.S. LEE, The biocompatibility of SLA-treated titanium implants. Biomed Mater, 3(2), DOI: 10.1088/17486041/3/2/025011 (2008).

17. B. MÖLLER, H. TERHEYDEN, Y. AÇIL, N.M. PURCZ, K. HERTRAMPF, A. TABAKOV, E. BEHRENS, J. WILTFANG, A comparison of biocompatibility and osseointegration of ceramic and titanium implants: an in vivo and in vitro study. Int $\mathrm{J}$ Oral Maxillofac Surg, 41(5), 638-645 (2012).

18. C. MISCH, Dental Implant Prosthetics. Elsevier Mosby, St. Louis, Missouri, 2nd Ed. (2015).

19. M.M. OSWAL, U.N. AMASI, M.S. OSWAL, A.S BHAGAT. Influence of three different implant thread designs on stress distribution: A three-dimensional finite element analysis. J Indian Prosthodont Soc, 16(4), 359-365 (2016).

20. K. KIESWETTER, Z. SCHWARTZ, The role of implant surface characteristics in the healing of bone. Crit Rev Biol Med, 7(4), 329-345 (1996).

21. D. BUSER, R.K. SCHENK, S. STEINEMANN, J.P. FIORELLINI, C.H. FOX, S. STICH, Influence of surface characteristics on bone integration of titanium implants. A histomorphometric study on miniature pigs. J Biomed Mater Res, 25(7), 889-902 (1991).

22. M. WONG, J. EULENBERGER, R. SCHENK, E. HUNZIKER, Effect of surface topology on the osseointegration of implant materials in trabecular bone. J Biomed Mater Res, 29(12), 1567-1575 (1995).

23. C.M. STANFORD, Surface Modification of Biomedical and Dental Implants and the Processes of Inflammation Wound Healing and Bone Formation. Int $\mathrm{J}$ Mol Sci, 11(1), 354-369 (2010).

24. D. ARYA, S. TRIPATHI, R. BHARTI, Role of surface topography of titanium endosseous implants for improved osseointegration. J Dent Implant, 2(2), 93-96 (2012).

25. C. OGUNSALU, A. ARCHIBALD, C. EZEOKOLI, Emerging applications of an experimental single photon emission computed tomography: an analysis of 16 areas of interest in the pig's model. West Indian Med J, 61(9), 916-920 (2012).

26. C. OGUNSALU, A. ARCHIBALD, J. WATKINS, C. STOIAN, C. EZEOKOLI, H. DAISLEY, C. LEGALL, S. LORDE, K. JACKSON, D. JAGGERNAUTH, A. NELSON, N. MUNGAL, Comparative study of the osteoblastic activity of two implant systems (Endopore versus Entegra) utilizing single photon emission computed tomography (SPECT): experimental study in pigs model. West Indian Med J, 62(2), 145-148 (2013).

27. K. KON, M. SHIOTA, M. OZEKI, S. KASUGAI, The effect of graft bone particle size on bone augmentation in a rabbit cranial vertical augmentation model: a microcomputed tomography study. Int J Oral Maxillofac Implants, 29(2), 402-406 (2014).

28. V. NIMIGEAN, A. POLL, V.R. NIMIGEAN, S.A. MORARU, D.G. BADITA, D.L. PAUN, The Routine and Specialised Staining for the Histologic Evaluation of Autogenous Mandibular Bone Grafts. An experimental study. Rev Chim (Bucharest), 69(5), 1106-1109 (2018).

29. V. NIMIGEAN, A. POLL, C.A. MINCULESCU, V.R. NIMIGEAN, S.A. MORARU, M.J.R. VÎRLAN, R.A. BĂLĂCEANU, D.L. PĂUN, Immunohistochemical evaluation of autogenous mandibular bone grafts integration: An experimental study. Rom Biotechnol Lett, 24(2), 229-235 (2019).

30. V. NIMIGEAN, V.R. NIMIGEAN, D.I. SALAVASTRU, S. MORARU, L. BUTINCU, R.V. IVASCU, A. POLL, Immunohistological aspects of the tissues around dental implants. Conference: $5^{\text {th }}$ Congress of the World-Federationfor-Laser-Dentistry/6th International Conference on Lasers in Medicine, Location: Bucharest, Romania, 07-09.05.2015. Book Series: Proceedings of SPIE, vol.: 9670, Published: 2016. DOI: $10.1117 / 12.2197741$.

31. M.J. TUCULINA, M. RAESCU, I.T. DASCALU, M. POPESCU, C.F. ANDREESCU, C. DAGUCI, C.N. CUMPATA, V.R. NIMIGEAN, I.M. BANITA, Indirect pulp capping in young patients: immunohistological study of pulp-dentin complex. Rom J Morphol Embryol, 54(4), 1081-1086 (2013).

A. KNIGHT, Non-animal methodologies within biomedical research and toxicity testing. ALTEX, 25(3), 213-231 (2008).

32. M. LEIST, S. KADEREIT, S. SCHILDKNECHT, Food for thought... on the real success of $3 R$ approaches. ALTEX, 25(1), 17-32 (2008).

33. W. LILIENBLUM, W. DEKANT, H. FOTH, T. GEBEL, J.G. HENGSTLER, R. KAHL, P.J. KRAMER, H. SCHWEINFUR TH, K.M. WOLLIN, Alternative methods to safety studies in experimental animals: role in the risk assessment of chemicals under the new European Chemicals Legislation (REACH). Arch Toxicol, 82(4), 211-236 (2008). 